\title{
Noonan syndrome an overview and a case description from Astana,Kazakhstan
}

\author{
Sholpan Kairmukhanova ${ }^{1}$, Adila Izgutdina ${ }^{2}$, Galymzhan Kuatbay ${ }^{2}$
}

${ }^{1}$ Department of pediatrics, Republican diagnostic center of the corporate fund "UMC», Astana, Kazakhstan ${ }^{2}$ Nazarbayev University School of Medicine, 3rd year student, Astana, Kazakhstan

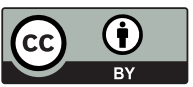

This work is licensed under a Creative Commons Attribution 4.0 International License

J CLIN MED KAZ 2017; 3(45 SUPPL 3):118-120 Corresponding author: Sholpan Kairmukhanova, Department of pediatric, Republican diagnostic center of the corporate fund «UMC». Address: Astana, Kazakhstan, St. Syganak 2; Telephone number: +7 (747) 39428 85; E-mail: sholpan.kairmuhanova@mail.ru

\section{ABSTRACT}

Noonan syndrome is an autosomal dominant genetic disorder characterized by facial dysmorhpic features, short stature and heart defects, such as pulmonary valve stenosis and heart hypertrophy (Roberts et al., 2013). The pathologic features are caused by the genetic mutations in the RAS-MAPK pathway signaling proteins, such as PTPN11. These mutations also predispose Noonan patients to risks of developing cardiovascular, myeloproliferative, lymphatic system disorders. Therefore we recommend raising awareness and increasing vigilance for these cases as the Noonan syndrome patients require special care of a multidisciplinary team of healthcare professionals to address their multiple health concerns and improve their outcomes.

Key words: Noonan syndrome, rare disease, genetic disease, RAS-MAPK mutation, PTPN11 mutation, Noonan Syndrome in Kazakhstan, rare diseases in Kazakhstan

\section{НУНАН СИНДРОМЫ: ҚАЗАҚСТАН, АСТАНАДАҒЫ КЛИНИКАЛЫҚ} ЖАҒДАЙЫН ШОЛУ ЖӘНЕ СИПАТТАМАСЫ

Қайырмұханова Ш.Қ. ${ }^{1}$, Изгутдина А. ${ }^{1}$, Қуатбай Ғ. ${ }^{1}$

'Педиатрия бөлмесі, «UMC» корпоративтік қорының Республикалық диагностикалық орталығы, Астана, Қазақстан

${ }^{2}$ Назарбаев Университеті, Медицина Мектебі, Астана, Қазақстан

Нунан синдромы бет-келбетінің дисморфты жүйесімен, аяқ-қолдарының қысқа боп жетілуімен және өкпе клапаны стенозы мен жүрек гипертрофиясы сынды белгілерімен көрінетін генетикалық аутосомды-доминантты ауруы. Патологиялық сырт келбеті RAS-MAPK сигналды жолындағы протеинінің генетикалық мутациясы себебінен туындайды. Оған қоса, аталған мутация жүрек-қан тамырлар ауруына, миелопролиферативті және лимфатикалық жүйенің ауруларына әкеп соқтырады. Нyнан синдромы пациенттерінің диагностикалық және емдеу нәтижелері тұрғысынан арнайы қамқорлық талап ететіндіктен, біздің ұсынысымыз, Нунан синдромы туралы кеңірек ақпарат таратып, емдік-диагностикалық мәселелерін шешу жолдарымен денсаулық сақтау ұйымдарын құлағдар ету.

Кілт сөздер: Нунан синдромы, сирек кездесетін аурулар, генетикалық аурулар, RAS-MAPK мутациясы, PTPN11 мутациясы, Қазақстандағы сирек кездесетін аурулар, Қазақстандағы Нунан синдромының жағдайы

\section{СИНДРОМ НУНАН: ОБЗОР И ОПИСАНИЕ КЛИНИЧЕСКОГО СЛУ- ЧАЯ В АСТАНЕ, КАЗАХСТАН \\ Каирмуханова Ш.К. ' , Изгутдина А. ${ }^{1}$, Куатбай Г. \\ 'Отдел педиатрии, Республиканский диагностический центр корпоративного фонда «UMC», Астанак., Казахстан \\ ${ }^{2}$ Назарбаев Университет, Школа Медицины, г. Астана, Казахстан}

Синдром Нунана является аутосомно-доминантным генетическим расстройством, характеризующимся лицевыми дисморфическими особенностями, коротким ростом и дефектами сердца, такими как стеноз легочного клапана и гипертрофия сердца. Патологические особенности вызваны генетическими мутациями сигнальных белков пути RAS-MAPK, такими как PTPN11. Эти мутации также предрасполагают пациентов Нунана к рискам развития сердечно-сосудистых, миелопролиферативных, лимфатических системных расстройств. В связи с этим, мы рекомендуем повысить осведомленность и повысить бдительность в отношении этих случаев, поскольку пациенты с синдромом Нунана требуют особой о многодисциплинарной группе здравоохраненния для решения их многочисленных проблем со здоровьем и улучшением результатов лечения

Ключевые слова: Синдром Нунана, редкие болезни, генетические болезни, RAS-MAPK мутации, PTPN11 мутации, Случай синдрома Нунана в Казахстане, редкие заболевания в Казахстане

\section{Genetic etiology}

Noonan syndrome is a genetic disorder characterized by multiple dysmorphic features such as face and musculoskeletal deformity, heart defects such as pulmonic stenosis and hypertrophy as well as short stature, atypical pigmentation patterns, lymphatic malformations and cryptorchidism. It has an autosomal dominant pattern of inheritance (Roberts et al., 2013). The disorder is characterized with a somewhat high prevalence 
of 1 to 1000-2500 live births (Van der Burgt, 2007).

A significant proportion of Noonan syndrome cases are due to a genetic mutation in one of the RAS-MAPK pathway genes (Roberts et al., 2013). RAS-MAPK is a pathway through which extracellular agents (hormones, growth factors) interact with cell signaling molecules and enact cell differentiation, metabolism and proliferation (Roberts et al., 2013). It begins with ligand binding and subsequent phosphorylation of cell surface receptors at cytoplasmic side. Binding stimulates recruitment of adaptor proteins that bind to the guanine nucleotide exchange factors such as SOS, that convert inactive, RAS bound to GDP to an active form bound to GTP (Roberts et al., 2013). Active RAS can then activate the RAF - MEK - ERK cascade by phosphorylation, where ERK activates transcription through entering nucleus and acting as a transcription factor to initiate a certain cell response (Roberts et al., 2013). The disease is brought on by the mutations in the proteins that take part in this pathway, and these mutations usually cause it to be overactive, increasing signaling through this pathway (Roberts et al., 2013).

In almost $50 \%$ of NS patients a gain of function mutations in PTPN11 is present. Pulmonary valve stenosis is usually a characteristic pathology in the patients with this mutation, whereas hypertrophic cardiomyopathy is frequently found in patients without this mutation (Van der Burgt, 2007). PTPN11 encodes SHP2, a signaling protein involved in cardiac semilunar valvulogenesis, and the missense mutations are situated in regions responsible for interaction and activation of the protein, resulting in prolonged activation.

The most prevalent PTPN11 mutation is A to G substitution at nucleotide 922, which is familiar and does not usually cause a pathological phenotype, whereas $\mathrm{C}$ to $\mathrm{T}$ substitution at nucleotide 218 predisposes to a myeloproliferative disorder (Van der Burgt, 2007). Mutations in PTPN11 are associated with glial tumors, multiple giant cell lesions (synovitis), high levels of growth hormone and low IGF1 levels (Roberts et al., 2013).

\section{Clinical signs}

Noonan syndrome is characterized with several deformities. The facial dysmorphism includes hypertelorism, ptosis, ears rotated posteriorly, prominent nasolabial folds, micrognatia, short neck with a low hairline at the back, webbing (Van der Burgt, 2007). Short stature is especially prevalent during adolescence and bone growth is usually delayed by 2 years (Van der Burgt, 2007).

Congenital heart defects in children with Noonan most frequently include stenosis of pulmonary valve in 50-62\% of cases, hypertrophic cardiomyopathy in $20 \%$, other atrial and ventricular defects are less common, persistent ductus arteriosus is in 3\% of cases, as well as arteriovenous malformations, such as aneurisms (Van der Burgt, 2007, Roberts et al., 2013). The ECG findings are wide QRS, negative wave in left precordial lids as well as giant $\mathrm{Q}$ waves and left axis deviation (Roberts et al., 2013).

With regards to stature, the children with Noonan syndrome are born with normal weight, which may be due to edema (Van der Burgt, 2007). However, over $60 \%$ of children will experience failure to thrive, feeding difficulties, frequent vomiting and gastroesophageal reflux syndrome (Van der Burgt, 2007). The growth is below 3rd centile, adolescent growth spurt usually delays and is less than in normal children or does not occur, the height attained in adulthood is lower than the 3rd centile of general population (Van der Burgt, 2007).

Children with mutation in PTPN11 respond better to treatment with growth hormone (Van der Burgt, 2007). 70-95
$\%$ of patients have skeletal deformities, such as superior pectus carinatum and inferior pectus excavatum, scoliosis (Roberts et al., 2013, Van der Burgt, 2007). More than 70\% of males are born with cryptorchidism and Sertoli cell dysfunction, whereas female fertility is not affected (Roberts et al., 2013, Van der Burgt, 2007).

Tendency for coagulation disorders is present in 55\% of patients, due to the deficit of factors VIII, XI and XII, thrombocytopenia, abnormally functioning platelets (Van der Burgt, 2007). Patients are also predisposed to several blood cancers, such as acute myelogenous leukaemia, B-cell acute lymphoblastic leukaemia and juvenile myelomonocytic leukemia (JMML), which has a better prognosis in Noonan patients compared to general population (Roberts et al., 2013, Aoki et al. 3013). Hepatomegaly and splenomegaly can be present at birth and infancy, it is unrelated to the heart failure (Van der Burgt, 2007).

There are common skin signs, such as abnormalities of pigmentation, pigmented

nevi in $25 \%$ of patients and cafe-au-lait spots in $10 \%$ (Van der Burgt, 2007). Lymphatic system problems, such as hydrops fetalis are common (Van der Burgt, 2007). Ear problems, such as otitis media, sensorineural hearing loss of a low frequency range in $10 \%$ and of high frequency range in $25 \%$ of patients (Van der Burgt, 2007).

The disease is also associated with learning difficulties with a wide range of IQ, attention deficit hyperactivity disorder, behavioral issues and speech problems (Roberts et al., 2013). There is a growth and developmental delay, as sitting milestone is achieved at 10 month, walking at 21 and talking at 31 month (Van der Burgt, 2007).

\section{Case description}

The disease prevalence has not been reported for Kazakhstan or Central Asian region. Discussion will follow with the description of a patient in our care.

Chief Complaint

The patient's mother came to the physician with the complaint of developmental delay of her 4 year old daughter, such as inability of the child to walk on her own, walking with support, problems with speech: speech is unclear, pronounces individual syllables. The girl has poor appetite and does not eat solid food. On the current doctor's visit, the mother is concerned about the child's hyperthermia, generalized weakness, feeding difficulties.

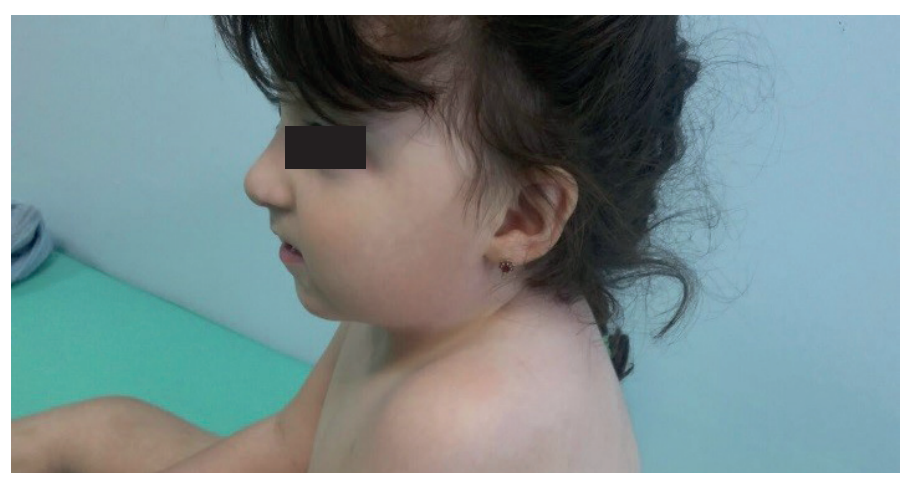

Fig 1: Low-set ears, wide neck

\section{History of present illness}

The child has been ill since birth. Has previously been under the care of neuropathologist with the diagnosis of encephalopathy, and cardiologist with a diagnosis of congenital 

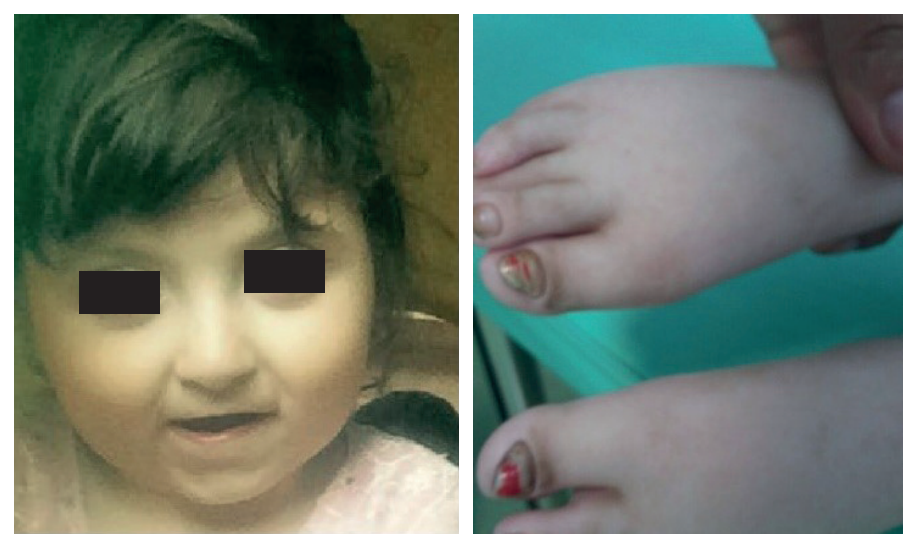

Fig 1: Moon face,small open mouth

Fig 2: Talipesequinovarus, naildeformity

heart defect - patent ductus arteriosus. Previously has underwent a surgery at the age of 8 months for polydactyly of the left hand.

\section{Life history}

Child from second pregnancy, with gestational toxicosis, poisoning with acetone fumes inhalation. Labor with cesarean section, weight at birth - 3900 g. Underwent resuscitation.

\section{Status}

The patient is weak, febrile, and has been in this condition for two months. On examination she is stable. The patient has a notable short stature with a height of $88 \mathrm{~cm}$ (with a normal of 98.5-104 cm for her age), lag of physical development, weight of $12 \mathrm{~kg}$ (with a normal $15-18 \mathrm{~kg}$ ). Notable is the presence of anomalies, such as short, webbed neck, hypertelorism, antimongoloid slant of eyelids, low-set ears, atypical situation of scapulae, deformity of the phalanges of fingers, deformity of the ankle joint - talipes equinovarus, micrognathia, incorrect teeth growth and pathological dental occlusion, moon face and permanently open small mouth.

Subcutaneous adipose tissue is moderately developed; turgor is preserved. On auscultation, vesicular breathing sounds in the lungs. Heart tones are rhythmical, with characteristic murmur. The abdomen is soft. Spleen is not enlarged. Liver enlargement on palpation +2 . Stools: prone to constipation. Urination is normal

Laboratory studies demonstrated the following abnormalities:

On $\mathrm{CBC}$ : low hemoglobin, $\mathrm{MCH}, \mathrm{MCHC}$, increase of lymphocytes, monocytes, ESR
Doppler echocardiography: congenital heart defect, aortic insufficiency - stage 1 , condition after closure of patent ductus arteriosus with an occluder.

Head CT: two sided maxillary sinusitis

Nephrologist: congenital defect of urinary tract - bilateral kidney hypoplasia

Gastroenterologist: protein-energy malnutrition - stage 2, hepatomegaly

Cytogenetic analysis: female karyotype, no chromosomal abnormalities, conclusion: syndrome Noonan.

to teething.

The current presentation is due to maxillary sinusitis due

\section{Discussion}

The prevalence of the disease in Kazakhstan has not been studied before. It is important to raise awareness and increase vigilance with regards to this condition, as such characteristic morphological features allows for clinical diagnosis.

In this particular case, the patient was managed incorrectly, because she was not diagnosed early enough. She was treated for cerebral palsy and other neurological conditions due to developmental delay. Her heart defect was closed later in life when she was three. If the diagnosis was determined earlier, her health concerns could have been addressed earlier and unnecessary overtreatment could have been avoided.

Therefore, because the disorder is usually accompanied with a risk of congenital heart defects, coagulopathies, lymphatic and urinary tract malformations, risks of developing leukemia and other cancers (Roberts et al., 2013), the care has to be provided by a multidisciplinary team of doctors, such as cardiologists, clinical geneticists, pediatricians (Roberts et al., 2013) with these specific risks in mind. Another important aspect of diagnosis is the genetic tests to determine the type of mutation the patient carries, that although could be a tremendous help in diagnosis, are not accessible in Kazakhstan.

\section{Conclusion}

Noonan Syndrome is the rare genetic disorder, which is not described in Kazakhstan before being underdiagnosed or misdiagnosed so far. Treatment of organ defects secondary to genetic mutation is most effective if the disease is diagnosed in its early stages. Therefore, it is important to provide learning seminars raising awareness about Noonan syndrome among primary care physicians.

\section{References:}

1. Aoki, Y., Niihori, T., Banjo, T., Okamoto, N., Mizuno, S., Kurosawa, K., Hoshika, T. Gain-of-function mutations in RIT1 cause Noonan syndrome, a RAS/MAPK pathway syndrome. The American Journal of Human Genetics. 2013; 93(1):173-180.

2. Roberts, A. E., Allanson, J. E., Tartaglia, M., \& Gelb, B. D. Noonan syndrome. The Lancet. 2013; 381(9863): $333-342$.

3. Van der Burgt, I. Noonan syndrome. Orphanet journal of rare diseases. 2007; 2(1)/ 